\title{
Structural and textural response to dynamics of fluvioglacial processes of the Rzymsko esker sediments, Central Poland
}

\author{
Małgorzata Frydrych \\ University of Lodz, Faculty of Geographical Sciences, Department of Physical Geography, \\ ul. Narutowicza 88, 90-139 Łodź, Poland; e-mail: malgorzata.frydrych@geo.uni.lodz.pl \\ (c) 2016 Authors. This is an open access publication, which can be used, distributed and reproduced in any medium according
to the Creative Commons CC-BY 4.0 License requiring that the original work has been properly cited.
}

Received: 2016-10-28; accepted: 2017-01-18

\begin{abstract}
The study was conducted in the Rzymsko esker, in the Eastern part of the Turek Upland Plain, within the range of the Warta Glaciation (Saalian II). The form was accumulated in a tunnel valley, which was partially filled with esker sediments. Lithofacies analysis, extended by a detailed analysis of clasts, made it possible to identify a considerable variability of sedimentation conditions. At the initial stage, transport and accumulation of sediments took place in the conditions of high energy hydraulic flows or hyperconcentrated flows. The flow energy rose cyclically, which was recorded as sediments coarsening. Deposits of boulders as well as massive and cross-bedded gravels were identified, a record of catastrophic glacial floods. During the later stage of esker formation, sandy and gravelly sediments were accumulated in an open crevasse. The strong erosional force of subglacial water is confirmed by an extremely high content of local rocks in the gravelly fraction (30-87\%) and its very good roundness. Zingg shape analysis (1935) revealed a clear predominance of oblate forms among local clasts and equant fennoscandian erratics. A dependency was also found between the processing method and petrographic characteristics.
\end{abstract}

Keywords: glacifluvial sediments, clast shape, esker, Central Poland, Warta Glaciation

\section{INTRODUCTION}

Fluvioglacial processes responsible for forming the Rzymsko esker operated in a subglacial tunnel valley and an open crevasse (Jaksa 2003). These environments have been described in the literature (Warren \& Ashley 1994, Brennand 1994, 2000, Brennand \& Shaw 1996, Delaney 2001, Fard \& Gruszka 2007, Pisarska-Jamroży \& Zieliński 2012). However, the significant dissimilarity of conditions present in individual cases still leaves many issues to be discussed. Sediments analysed in eskers prove diverse dynamics of the environment of their deposition, which is reflected in the different lithofacies and textural characteristics of the sediments. In the sediments of the Rzymsko esker, a high content of local rocks and their good roundness have been reported (Jaksa 2003, Czyż et al. 2008, Rdzany 2008, 2009), but no more detailed analyses have been conducted so far. In order to precisely determine the characteristic features of the sediments, the author conducted shape and roundness analyses of gravel clasts and determined the share of local rocks. Determination of textural characteristics of sediments is important for estimating the length of sediment transport and erosional forces which operated in the given environment. The conditions present in tunnel valleys or crevasses provide information on the features of the ice sheet and often also on the nature of its deglaciation (Delaney 2001). The aim of the conducted research is to determine 
the conditions present during the deposition of sediments of the Rzymsko esker and to provide a better understanding of the relation between the structural and textural features of the sediments and the dynamics of the environment. The Rzymsko esker was formed during Saalian II (Fig. 1A) and broadening of the knowledge about the processes which occurred in the ice sheet drainage system is another aim of the study.

\section{GEOLOGICAL SETTING}

The Rzymsko research site is found in the southern part of the esker ridge, which is located in the central-eastern part of the Turek Plateau, according to regionalisation of Kondracki (2001) (Fig. 1B). The esker's orientation is nearly meridional, with a slight NNW to SSE deviation. Continuity of the ridge is broken by the Teleszyna and Struga Mikulicka valleys, which divide it into three sections (Figs 1B, 2). The longest, 4-kilometre southern fragment stretches between Rzymsko in the south and Kolonia Linne in the north. It reaches the elevation of about $147 \mathrm{~m}$ a.s.l. at its highest point. The relative height values between the form's ridge and base reach $20 \mathrm{~m}$, which makes it clearly prominent in the landscape. The central section runs along the Teleszyna valley to Mikulice in the north. It is characterised by less diverse relief. The last section, located to the north of Mikulice, is recognised as a kame in the geological map (Czyż et al. 2004), and as an esker in the geomorphological sketch (Czyż et al. 2008). The author shares the opinion that this form is a continuation of the esker. The esker partially fills a tunnel valley (Czyż et al. 2008, Frydrych \& Rdzany 2015), a fragment of which stretches along the eastern edge of the landform (Fig. 2).

The study area is located in the central part of the Mogilno-Łódź basin. The bedrock is built of Maastricht sediments, dominated by grey, sandy and clayey marls at some places (Czyż et al. 2008). The material was eroded and transported by subglacial water. The analysed form is surrounded mainly by flat and undulating moraine plateaus and fluvioglacial plains. The course of the Rzymsko esker corresponds to the Teleszyna valley, which once functioned as the outflow path of meltwater during deglaciation of the Warta ice-sheet, and its foundations are probably older than the
Odranian Glaciation (Klatkowa \& Załoba 1991). The Rzymsko esker and the dominating morphological and lithological features of the surrounding area were shaped during the Warta Glaciation (Saanian II), which was the most recent glaciation to encompass the analysed area (Fig. 1A).
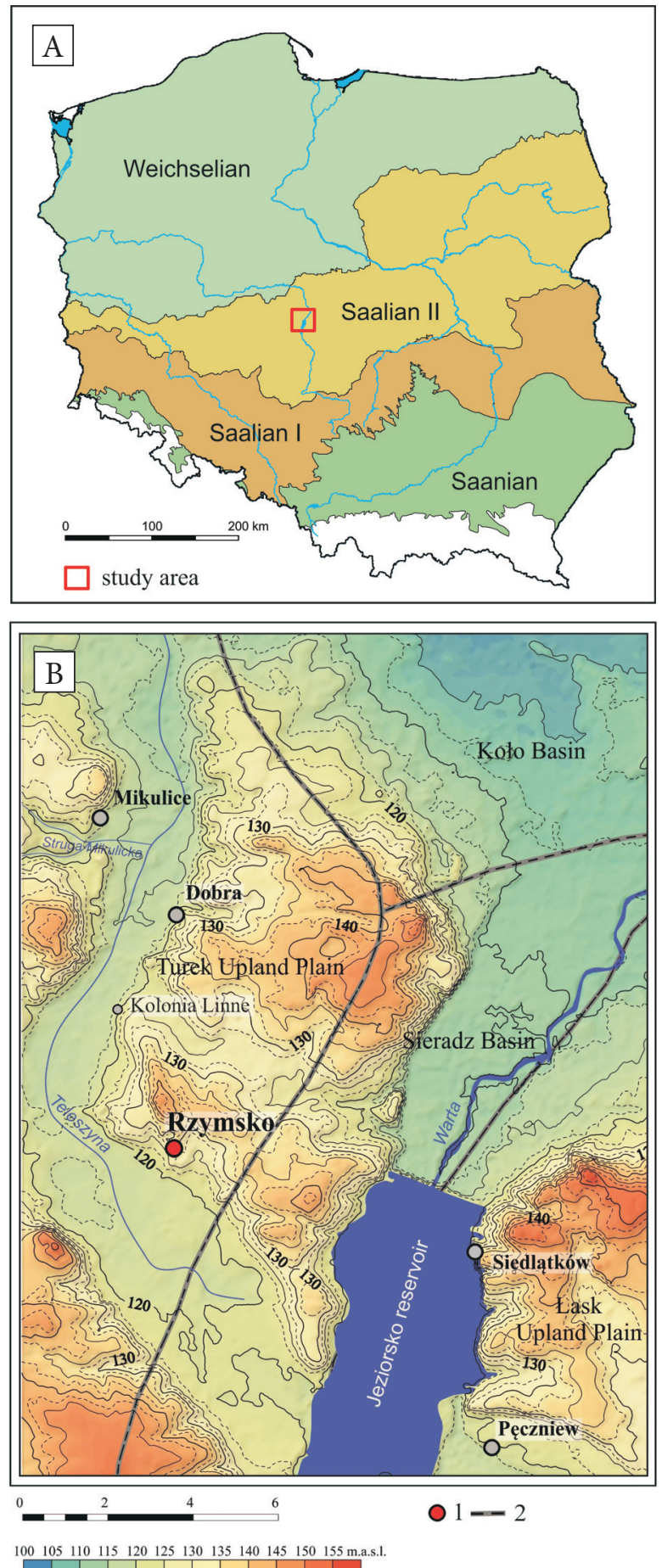

Fig. 1. Study area: A) Location against ranges of glaciation extents in Poland; B) Location of the research site (1) against the background of landscape relief and the physicogeographical divisions by Kondracki (2002) (2) 


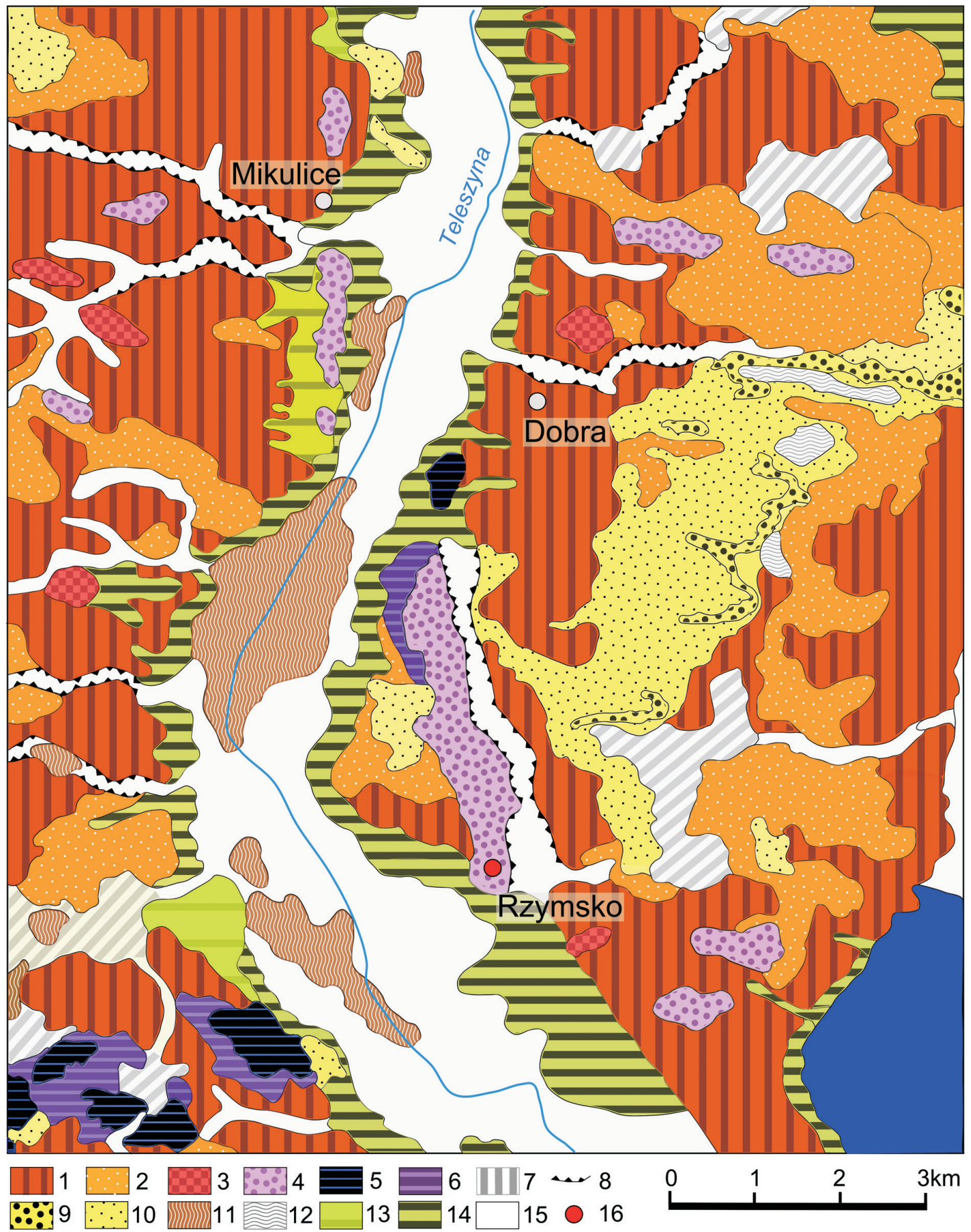

Fig. 2. Location of the research site (16) against the geomorphological forms on the basis of the modified geomorphological sketch (Czyż et al. 2008): 1 - moraine plateau, 2 - fluvioglacial plains, 3 - moraine hills, 4 - eskers and forms of crevasse accumulation, 5 - kames, 6 - kame terraces, 7 - kettle holes, 8 - tunnel valleys and meltwater valleys, 9 - dunes, 10 - sand plains, 11 - peat plains, 12 - dead ice holes, 13 - erosional high terraces, 14 - high terrace, 15 - bottoms of river valleys and flood plains

\section{METHODS}

The present research was conducted in a gravel pit in Rzymsko (Fig. 1B). The structure and texture of the sediments was determined using Miall's lithofacies code (1978) including its later modifications (Zieliński \& Pisarska-Jamroży 2012). Three thickness classes were defined for sediment description: small scale $(<6 \mathrm{~cm})$, medium scale $(6-30 \mathrm{~cm})$ and large scale (>30) (Pisarska-Jamroży 2006). 
For sediments of the gravelly fraction, analysis of clast shape and roundness was performed. At several spots of the outcrop, samples of gravelly sediments were taken, from which the $8-16 \mathrm{~mm}$ and $16-32 \mathrm{~mm}$ fractions, referred to as medium and coarse gravels according to Wentworth (1922), were isolated using screens. Then, 50 clasts from each fraction were selected and their length $\left(D_{L}-\right.$ long axis), width $\left(D_{I}-\right.$ medium axis $)$ and thickness $\left(D_{S}-\right.$ short axis) were measured. This was the base for calculating the elongation ratio: $D_{I} / D_{L}$, flatness ratio: $D_{S} / D_{I}$ (Zingg 1935) and maximum projection sphericity: $\psi_{p}=\left(D_{S}{ }^{2} / D_{L} D_{I}\right)^{1 / 3}$ (Sneed \& Folk 1958). A total of 700 clasts were analysed, including 200 clasts in the $16-32 \mathrm{~mm}$ fraction and 500 clasts in the $8-16 \mathrm{~mm}$ fraction. The relation between the elongation ratio and flatness ratio was used for drawing a Zingg diagram (1935). The diagram made it possible to divide the analysed clasts into four classes: oblate (disc), bladed, equant and prolate (rod). Roundness of the clasts was analysed by comparing their shape in the largest plane to the visual chart comparator by Krumbein (1941). The chart was used for distinguishing nine classes of roundness ( 1 - very angular, 9 - well rounded).

During field observations, a high content of local rocks was found in the gravelly and boulder formations. In order to analyse their content in more detail, the proportion of local clasts to fennoscandian ones was determined in the $8-16 \mathrm{~mm}$, $16-32 \mathrm{~mm}$ and boulder fractions $(>256 \mathrm{~mm})$. On the basis of the measurements, their shapes and roundness were compared.

In the coarse-grained sediments, the maximum particle size (MPS) was measured, as the mean value of the medium axis length $\left(D_{I}\right)$ of ten largest clasts in the stratum. When the measurement of $D_{I}$ was impossible due to the excessive size of the boulder in the outcrop, the largest visible diameter was measured. This parameter is regarded as one of the most adequate for determining flow competence (Bluck 1967, Brodzikowski 1992).

On the basis of grain size parameters of the sediments, a palaeohydrology analysis of meltwater flows that occurred were conducted. The measurement of MPS was a base for calculating average velocity $\left(V_{\mathrm{av}}\right)$. It was determined using the Costa (1983) formulae: $V_{\mathrm{av}}=0.18 D_{\mathrm{MPS}}{ }^{0.49}$, where $V_{\mathrm{av}}[\mathrm{m} / \mathrm{s}]$,
$D_{\text {MPS }}[\mathrm{mm}]$, which is used for gravels. Similar analyses have frequently been performed in palaeogeographic research (Zieliński 1993, Zieliński \& van Loon 2003, Pisarska-Jamroży \& Zieliński 2012, Szmańda 2010).

\section{FACIES DESCRIPTIONS AND DEPOSITIONAL CONDITIONS}

Esker sediments are characterised by very high diversity and vertical and horizontal variability. Its core is dominated by coarse-grained sediments, and the flanks - by fine-grained sediments, which is a typical feature of this type of forms (Michalska 1971, Brennand 1994). Within the outcrop, 14 lithofacies were identified, which were presented in Figures 3-5. The central part of the outcrop reveals a complex formed by BGm, BGp, GBp, Gp, Gt, Gm, SGp, Sp, Sl and Sh lithofacies, whereas the marginal parts contain Gm, SGp, Sp, Sl, Sh and Sr lithofacies. Sediment thickness in the outcrop is about $10 \mathrm{~m}$, which is only a fraction of the total thickness of sediments in the esker. Previous research (Jaksa 2003) conducted in the outcrop located to the north of the analysed one had revealed that at a greater depth, there is a severalmetre thick stratum of massive gravels with clastsupported texture.

\section{Coarse-grained sediments}

\section{Massive clast and sand-supported boulders and gravels (BGm)}

The BGm lithofacies occurs only in the esker core and reaches the thickness of about $0.6 \mathrm{~m}$. It is superimposed on a stratum of horizontally stratified gravels (Fig. 3A). These sediments are characterised by the presence of partially clast-supported and partially matrix-supported texture, made up of boulders and coarse and medium gravels. Maximum particle size (MPS) in the sediment is $44.4 \mathrm{~cm}$ and the largest measured diameter reaches $60 \mathrm{~cm}$. The boulder fraction is largely predominated by clasts of local rocks, characterised by very good processing and a high degree of roundness. This lithofacies originated as a result of a meltwater flood in a tunnel valley, which may have taken place after an episode of increased ice-sheet ablation or a release of a small subglacial reservoir. 

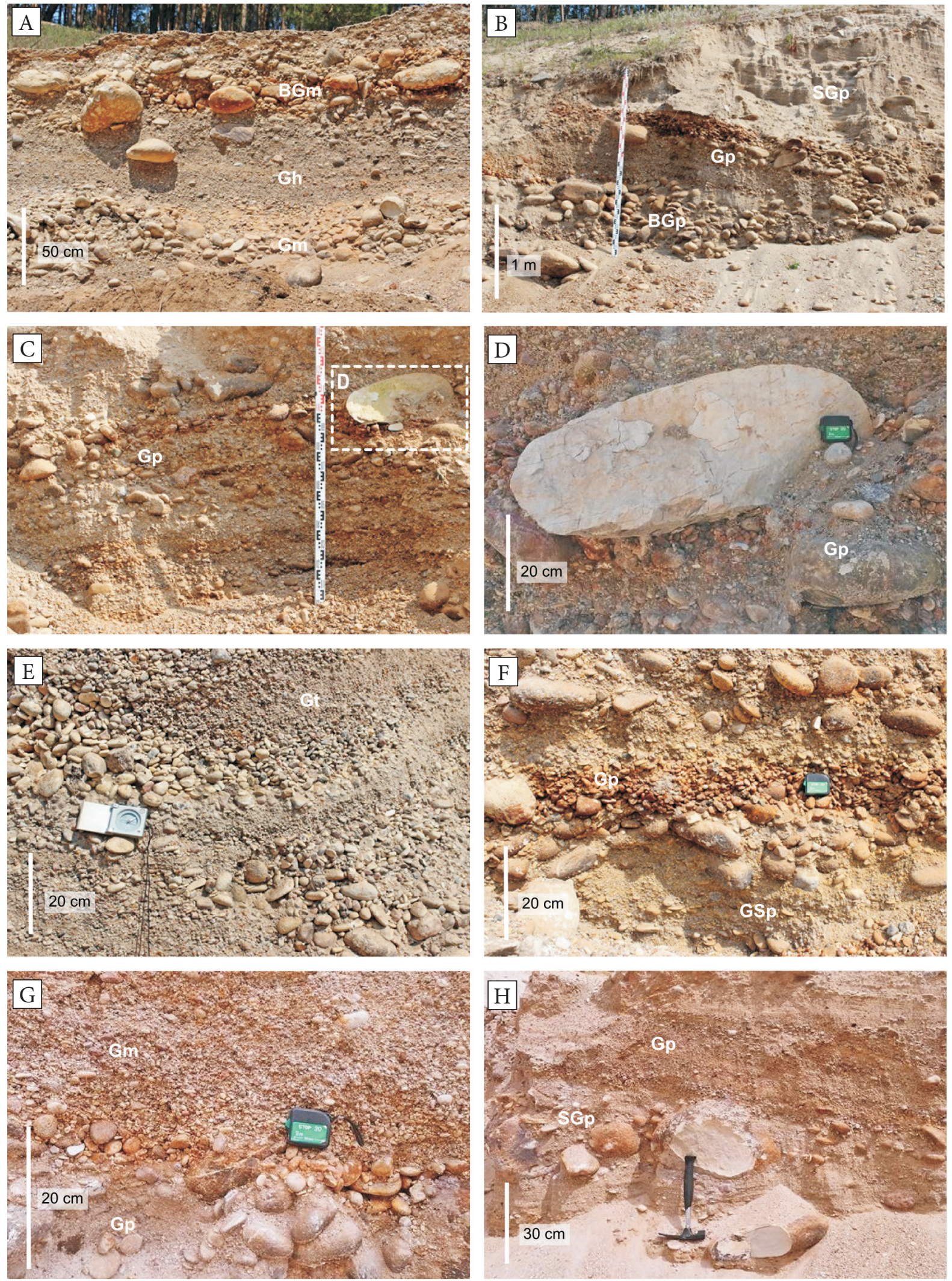

Fig. 3. Coarse-grained sediments: A) lithofacies of massive boulders and gravels and gravels with sandy matrix, separated with horizontally stratified gravels; B) planar cross-bedded gravels and sand-supported boulders and gravels; C) planar cross-bedded gravels in a large scale set; D) megaclast of local rocks in planar cross-bedded gravels; E) trough cross-bedded gravels with normal grading and openwork texture; F) planar cross-bedded gravels and sandy gravels with openwork structure; G) normal grading massive gravels; $H$ ) planar cross-bedded gravels and gravelly sands with megaclasts 
Transport occurred in a high-energy hyperconcentrated flow (Maizels 1991, 1993, Knudsen \& Russell 2002, Pisarska-Jamroży 2007). The material was accumulated very rapidly as a consequence of a sudden reduction of transport speed. Sediments of this type often constitute records of catastrophic flows (Maizels 1991, 1993, Zieliński 1993, Russell \& Marren 1999, Knudsen \& Russell 2002, Zieliński \& van Loon 2003, Fard \& Gruszka 2007).

\section{Planar cross-bedded clast and sand-supported boulders and gravels (BGp/GBp)}

Sediments of BGp and GBp lithofacies are revealed only in the central part of the form, and create the core of the esker. Their thickness in the outcrop reaches $1.5 \mathrm{~m}$. Along with Gp lithofacies, they form a single set of at least $5 \mathrm{~m}$ in thickness. They are dominated by clast-supported texture, made up of boulders and coarse and medium gravels with a high content of sandy matrix (Fig. 3B).

MPS reaches $63.9 \mathrm{~cm}$. The largest measured boulder diameter is $75 \mathrm{~cm}$, but the literature mentions clasts of up to $1 \mathrm{~m}$ (Czyż et al. 2008). Similarly to the BGm lithofacies, the boulder fraction is dominated by highly reworked local rocks (95\% of the 20 largest measured clasts were local rocks). The BGp and GBp lithofacies are a record of a flood in a tunnel valley. The transport took place in the conditions of a high-energy hydraulic flow, capable of traction-transporting of boulders. Sedimentation occurred in a deep channel with a catastrophically high flow discharge resulting from progradation of transverse bars (Baker 1984, Brennand\& Shaw 1996, Rudoy \& Baker 1993, Carrivick et al. 2004, Zieliński 2015).

\section{Planar cross-bedded gravels (Gp)}

The Gp lithofacies dominates in the central part of the esker, forming a considerable portion of its core. It is present in sets of medium and large scale, whose thickness exceeds $3 \mathrm{~m}$. Along with the BGp and GBp lithofacies, they form a set of more than $4 \mathrm{~m}$ of thickness. It also often alternates with the GSp lithofacies. The texture is made up of coarse and medium gravel and sparse boulders (Fig. 3C, 3D). Diversification of the content of coarse gravels and boulders is visible in the profile. Megaclasts of up to $65 \mathrm{~cm}$ were measured in the outcrop. Linear zones of larger concentration of coarser clasts are separated with zones with a significantly lower content of such clasts, which constitutes a record of variable flow energy in the tunnel valley. There are also Gp strata which consist only of fine and medium gravels, without any content of coarser fractions (Fig. $3 \mathrm{H}$ ). The sediments are dominated by matrix-supported texture and a high content of sandy matrix. They feature accumulations of coarse-gravelly clasts of local origin. There are instances of matrix-supported texture and strata of gravels devoid of matrix with openwork texture (Fig. 3F). They are one of the characteristic features of tunnel valleys and glacimarginal environments (Zieliński 1993, Maizels 1993, 1997, Fard \& Gruszka 2007, Pisarska-Jamroży 2007, Gruszka et al. 2011). Sediments with a high concentration of gravelly clasts exhibit a considerably lower thickness than poorly-sorted sediments. At some places, normal and reverse fractional grainsize distribution is visible, which is a record of the increasing and falling stages of flood. These sediments originated as a result of progradation of transverse bars or migration of 2-D dunes in flows that were heavily-loaded. The considerable thickness of sediments provides evidence for rapid aggradation and high supply of material (Jaksa \& Rdzany 2002, Gruszka et al. 2011). The Gp lithofacies represents the environment of highenergy flows.

\section{Massive gravels (Gm)}

The Gm lithofacies is found in the central part of the esker, where it lies unconformably upon sediments of the Gp lithofacies and reaches the thickness of up to $40 \mathrm{~cm}$. They exhibit normal fractional grain-size distribution and matrix-supported texture (Fig. 3G). The size of clasts decreases from medium to very fine gravels. Sediments of the $\mathrm{Gm}$ lithofacies are also revealed in the form of coarse gravels (cobble) with clast-supported texture without fractional grain-size distribution (Fig. 3A). Sedimentation of gravels with massive structure occurred in the conditions of supercritical flows, possibly in the conditions of upper flat bottom. That kind of sediments are interpreted as ones accumulated from a hyperconcentrated flow (Maizels 1993, Russel \& Maren 1999). 


\section{Trough cross-bedded gravels (Gt)}

The lithofacies is revealed in the central part of the esker. It occurs in large scale sets with thickness of up to $1.5 \mathrm{~m}$. In several strata, a clear fining of grain size towards the roof from medium and coarse gravels (pebble) to fine gravels (granule). Sediments of the Gt lithofacies are characterised by very good sorting, clast-supported texture and high packing density. Openwork texture is common (Fig. 3E). Their presence testifies to accumulation in the conditions of supercritical high-energy flows, during which finer grains were carried away (Maizels 1993, 1997, Pisarska-Jamroży 2007, Fard \& Gruszka 2007). The creation of openwork texture is considered as the result of effective sorting on the transverse bars surface. Sand was carried away in suspension, but energy of flow was too low to move bigger clasts (Wyżga 1993). Sediments of the Gt lithofacies originated as a result of migrating three-dimensional gravelly ripplemarks in channels of considerable depth and high flow competence (Brennand \& Shaw 1996, Carling 1996, Rudoy 2002, Fard \& Gruszka 2007). Directions of long axes of clasts are parallel to the general orientation of the form.

\section{Horizontally stratified gravels (Gh)}

Sediments of the Gh lithofacies are sporadic in the outcrop. They are mainly made up of medium and fine gravels with thickness of up to approximately $0.5 \mathrm{~m}$ (Fig. 3A). They are quite well sorted, but contain sparse megaclasts. They were accumulated from a traction carpet under conditions of upper flat bottom in upper flow regime (Zieliński 2015). Transport and sedimentation may have occurred under hydrostatic pressure in a tunnel valley, with its complete filling. The condition of upper flat bottom is believed to be easily available in the environment of tunnel valleys (Saunderson 1981).

\section{Planar cross-bedded sandy gravels and gravelly sands (GSp/SGp)}

The GSp lithofacies is common throughout the form, mostly as interbedding of the Gp lithofacies (Fig. 3F) or intermediate zone between the sediments of Gp and Sp lithofacies. Its thickness usually reaches several dozen centimetres. Sediments of the GSp lithofacies are mostly very poorly sorted. They contain megaclasts at some places. The
SGp lithofacies occurs mainly in lateral parts of the form and in its upper central part. Similarly to the GSp lithofacies, it sometimes interbeds with thicker sediments. It occurs in sets of medium and large scale and is characterised by poor sorting (Fig. 4A). These sediments originated as a result of progradation of transverse bars or migration of 2-D dunes in the conditions of high-energy flows. The megaclasts which are present in the sediment may come from the top of the channel, when sedimentation took place in subglacial conditions.

\section{Sand-supported massive gravels (GSm)}

Sediments of the GSm lithofacies occur in the upper, western part of the form, where their thickness reaches approximately $0.5 \mathrm{~m}$. They are characterised by clast-supported texture, made up of coarse and medium gravels, with a considerable content of fine-grained, mostly sandy, matrix. These sediments are in erosional contact with other lithofacies. Their features correspond most closely to intermediate flow, between cohesive and granular flow (Harvey 1984, Pisarska-Jamroży 2012).

\section{Sandy sediments}

\section{Planar cross-bedded sands (Sp)}

The Sp lithofacies is present throughout the outcrop, but its highest thickness values are reached in the central zone. It occurs in sets of medium and large scale. Thickness of individual bars reaches up to $2 \mathrm{~m}$. They are formed mainly by coarse sands. Significant admixtures of gravels are common. It is poorly sorted (Fig. 4B). The geometry of laminae is straight or concave. The Sp lithofacies is a record of transverse bars or migration of 2-D dunes which originated in deep channels. Accumulation took place at a considerable rate, which is evidenced by buried gravelly clasts. As the last link of the GBp - Gp - SGp - Sp sequence, it may correspond to the last falling stage of flood (Pisarska-Jamroży 2007).

\section{Trough cross-bedded sands and gravels and sands (SGt and St)}

Sediments of the SGt and St lithofacies are exposed fragmentarily in lateral zones of the form. The SGt lithofacies occurs in sets of medium and large scale, and the St lithofacies - in sets of medium and small scale (Fig. 4C). 

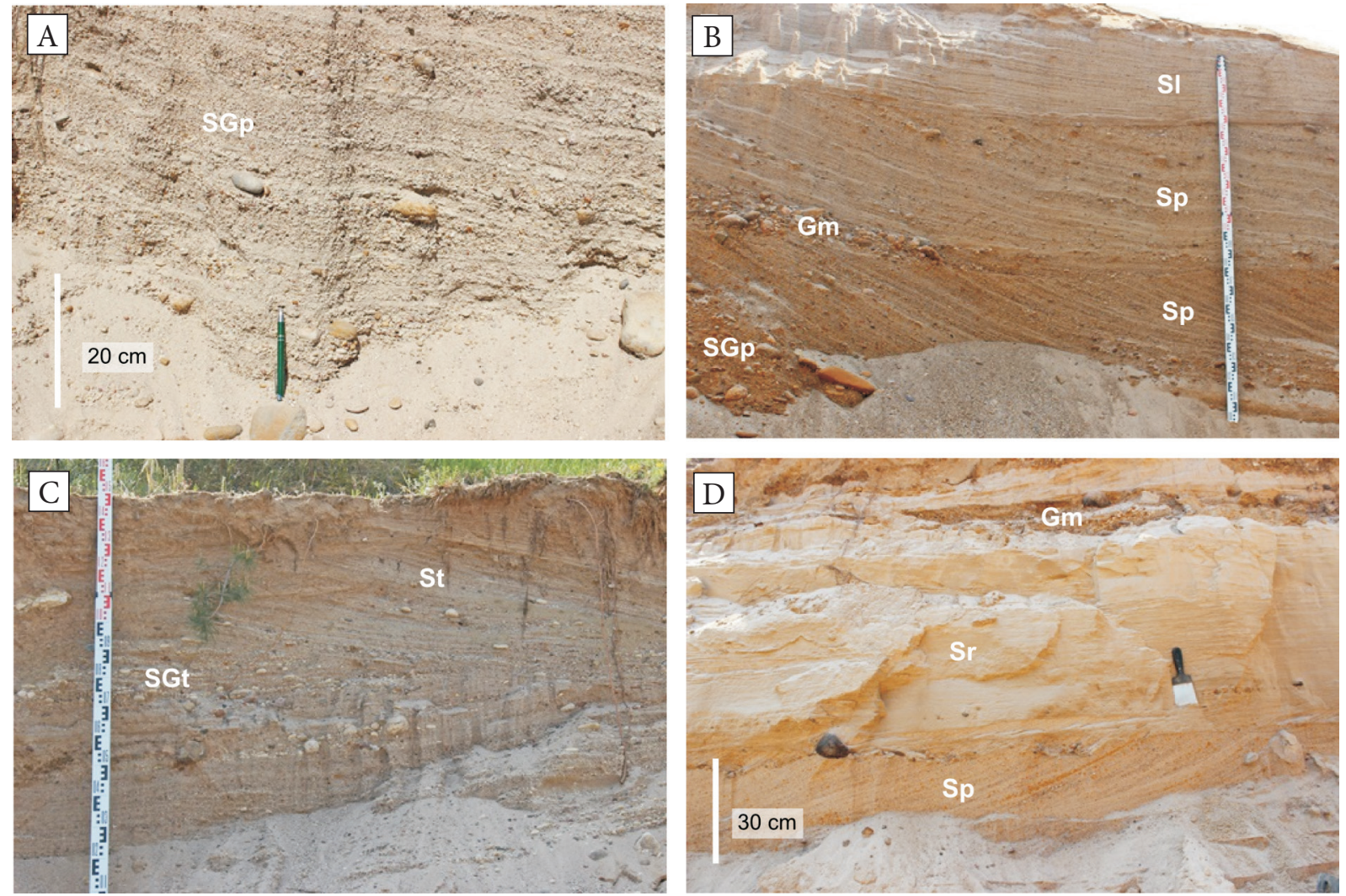

Fig. 4. Sandy sediments: A) planar cross-bedded gravelly sands in a large scale set; B) large-scale sets of planar cross-bedded sands and sands with gravel and low-angle cross-bedded sands; C) sediments of trough cross-bedded sands and sands with gravel; D) ripple cross-laminated sands separated from planar cross-bedded sands with a cobbls

In the eastern part of the outcrop, a very high content of local rocks is noticeable. Accumulation of SGt and St sediments took place as a consequence of migration of sandy megaripplemarks under conditions of lower flow regime in channels of significant depth (Pisarska-Jamroży \& Zieliński 2013).

\section{Low-angle cross-bedded sands (Sl)}

The Sl lithofacies occurs in the entire outcrop, in the central part of the vertical profile (Fig. 4B). It separates two complexes of coarse-clastic sediments. Its thickness may exceed $1.5 \mathrm{~m}$. It is formed mainly by poorly sorted coarse-grained sands with sparse clasts of fine-grained gravels. Sediments of the Sl lithofacies originated in the conditions of lower flow regime as a result of washing the ripplemarks out (Zieliński 1992, 2015).

\section{Ripple cross-laminated sands (Sr)}

Sediments of the Sr lithofacies were identified in the western, lateral part of the esker. Their thickness reaches approximately $1 \mathrm{~m}$. They are in erosional contact with the lower-lying sediments of the Sp lithofacies, from which they are separated by a thin stratum of pavement (Fig. 4D). In the upper part, they are cut by $\mathrm{Gm}$ sediments. The $\mathrm{Sr}$ lithofacies is made up of well sorted fine-grained sands. It was formed as a consequence of ripplemark migration in a fairly shallow channel, at low flow energy (Carling 2013, Pisarska-Jamroży \& Zieliński 2013).

\section{Horizontally stratified sands (Sh)}

The Sh lithofacies occurs in the upper part of the vertical profile of the sediments. The basal contact is not visible in the outcrop, which makes it difficult to precisely determine their thickness, which certainly exceeds $0.5 \mathrm{~m}$. It is formed by quite wellsorted, medium-grained sands. It is a record of accumulation in the conditions of upper flat bottom, probably in an already open channel (Maizels 1993, 1997, Zieliński 1992, Pisarska-Jamroży \& Zieliński 2013). 

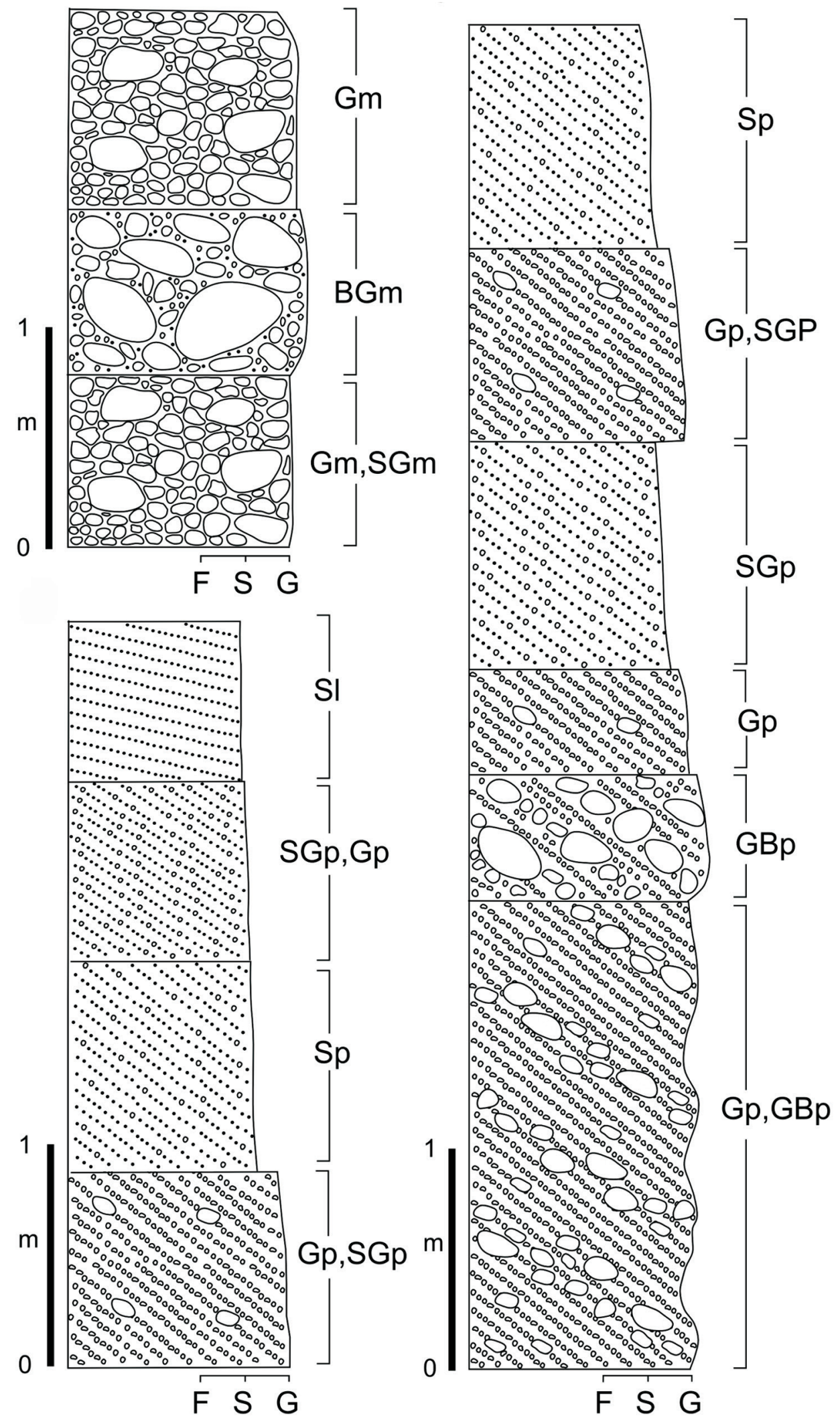

Fig. 5. Sedimentary logs from Rzymsko esker outcrop which show the most common lithofacies: BGm - massive gravelly boulders, Gm - massive gravels, SGm - massive sandy gravels, BGp - planar cross-bedded gravelly boulders, GBp - planar crossbedded boulder gravels, Gp - planar cross-bedded gravels, GSp - planar cross-bedded sandy gravels, Sp-planar cross-bedded sands, $\mathrm{Sl}$ - low-angle cross-bedded sands 


\section{FEATURES OF DEPOSITS AND INTERPRETATION}

In the analysed samples of gravels, the proportion of local rocks to fennoscandian rock clasts was determined, and was found to vary considerably within the outcrop. The mean content of local clasts in the $16-32 \mathrm{~mm}$ fraction is $55.3 \%$, and in the $8-16 \mathrm{~mm}$ fraction $-46.2 \%$. The content of fennoscandian clasts is $44.7 \%$ in the $16-32 \mathrm{~mm}$ fraction and $53.8 \%$ in the $8-16 \mathrm{~mm}$ fraction. A slight majority of the analysed samples (57\%) was dominated by fennoscandian material, whose maximum content reached $70 \%$. In strata with a high share of local pebbles, their content was between $70 \%$ and even $87 \%$. A considerable share of local material in esker formations has been discussed in the literature before. Salamon (2009) determined its content in an esker near Gogolin at $30-60 \%$ in the gravelly fraction. The subglacial environment is usually characterised by high dynamics and erosional potential, which is why it generates deep tunnel valleys. In Poland, the valleys sometimes cut Quaternary sediments and make deep incisions in the Mesozoic bedrock. The local material of which the Rzymsko esker is built include mainly Cretaceous marls, which were eroded and transported by subglacial water along the glacial drainage line. The variable content of local rocks in individual samples provides evidence for changeable supply of eroded material in different periods of sedimentation.

In the medium-grained $(8-16 \mathrm{~mm})$ and coarsegrained $(16-32 \mathrm{~mm})$ gravel fraction, shape and roundness analysis of clasts was performed. While comparing the shape of clasts between the analysed fractions and clasts of local and fennoscandian erratics, some regularities may be observed. In both fractions of local clasts, the oblate class is by far predominant (Figs 6-8). Grains of this class constitute on average $60.6 \%$ of all measured local grains in the $16-32 \mathrm{~mm}$ fraction and $67.5 \%$ in the 8-16 mm fraction. Further distribution of content of individual classes for the $16-32 \mathrm{~mm}$ fraction is as follows: $16 \%$ - prolate, $13.1 \%$ - bladed and $10.3 \%$ - equant, and for the $8-16 \mathrm{~mm}$ fraction: $15.2 \%$ bladed, $10.7 \%$ - prolate and $6.6 \%$ equant. The content of oblate grains for all samples of local clasts ranges from $45 \%$ to $80 \%$, bladed clasts - from $5.4 \%$ to $21.7 \%$, prolate - from $5.6 \%$ to $20.8 \%$ and equant - from $0 \%$ to $21.6 \%$. The percentage distribution of shapes for fennoscandian clasts is completely different, where the equant class grains clearly predominate (Figs 6-8) constituting on average $50.4 \%$ in the $16-32 \mathrm{~mm}$ fraction, and $48.65 \%$ in the $8-16 \mathrm{~mm}$ fraction. The second most frequently occurring are oblate clasts, which constitute $28.8 \%$ and $32.9 \%$ of grains respectively. Then there are the rod-like grains with $17.1 \%(16-32 \mathrm{~mm})$ and $13.1 \%$ $(8-16 \mathrm{~mm})$. Bladed grains were the least numerous class, with the content of $3.8 \%(16-32 \mathrm{~mm})$ and $5.4 \%(8-16 \mathrm{~mm})$. The content of the equant class in the analysed samples fluctuated between $35 \%$ and $71.4 \%$, oblate class grains - between $10.71 \%$ and $55 \%$, prolate grain class - between $0 \%$ and $25 \%$, and bladed class - between $0 \%$ and $16.1 \%$.

The mean value of the flatness ratio (Zingg $1935)$ in the analysed sample differs significantly between clasts of local rocks (0.555), and clasts of fennoscandian origin, for which it reaches 0.722 . It ranges between 0.231 and 1 for all clast (Fig. 9). In contrast, the elongation ratio (Zingg 1935) does not reveal any noticeable differentiation and amounts to 0.760 and 0.756 respectively. The range of values is between 0.438 and 1 (Fig. 9). A certain differentiation is visible in the distribution of the maximum projection sphericity (Sneed \& Folk 1958). The average value of this ratio for the local clasts is 0.602 , and for the fennoscandian clasts -0.729 . The values range between 0.376 and 0.965 (Fig. 9). The conducted analysis revealed that the dominant factor for shaping of clasts is their lithology.

Roundness analysis of clasts based on Krumbein's visual chart (1941) revealed that medium and coarse gravels in the esker are well reworked. Clasts of local origin are characterised by a higher degree of roundness, whose mean value for the $16-32 \mathrm{~mm}$ fraction is 0.77 and for the $8-16 \mathrm{~mm}$ fraction -0.8 . Therefore, they can be regarded as well rounded. The average roundness value for fennoscandian clasts is 0.62 and 0.61 respectively, which classifies them as rounded grains. The frequency distribution of individual roundness classes for the analysed samples is illustrated with Figures $6-8$. The diagrams show that roundness of the local rocks is most frequently recorded in the $7-9$ class. 

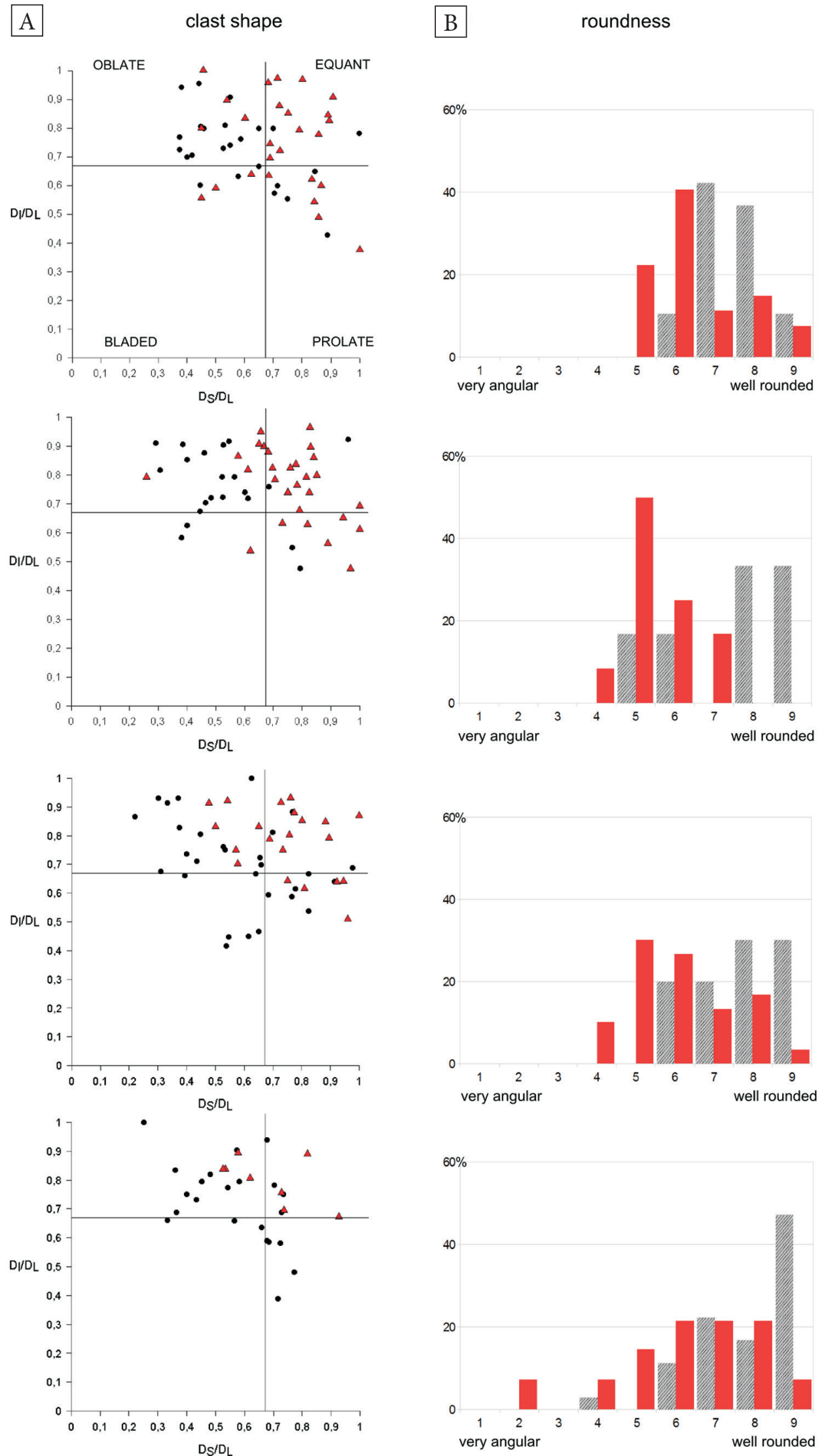

Fig. 6. Grain shape classification (A) using the Zingg diagram (1935) and roundness (B) (Krumbein 1941) in the 16-32 mm fraction of gravels of the Rzymsko esker: 1 - local rock, 2 - Fennoscandian erratic, 3 - local rocks, 4 - Fennoscandian erratics 

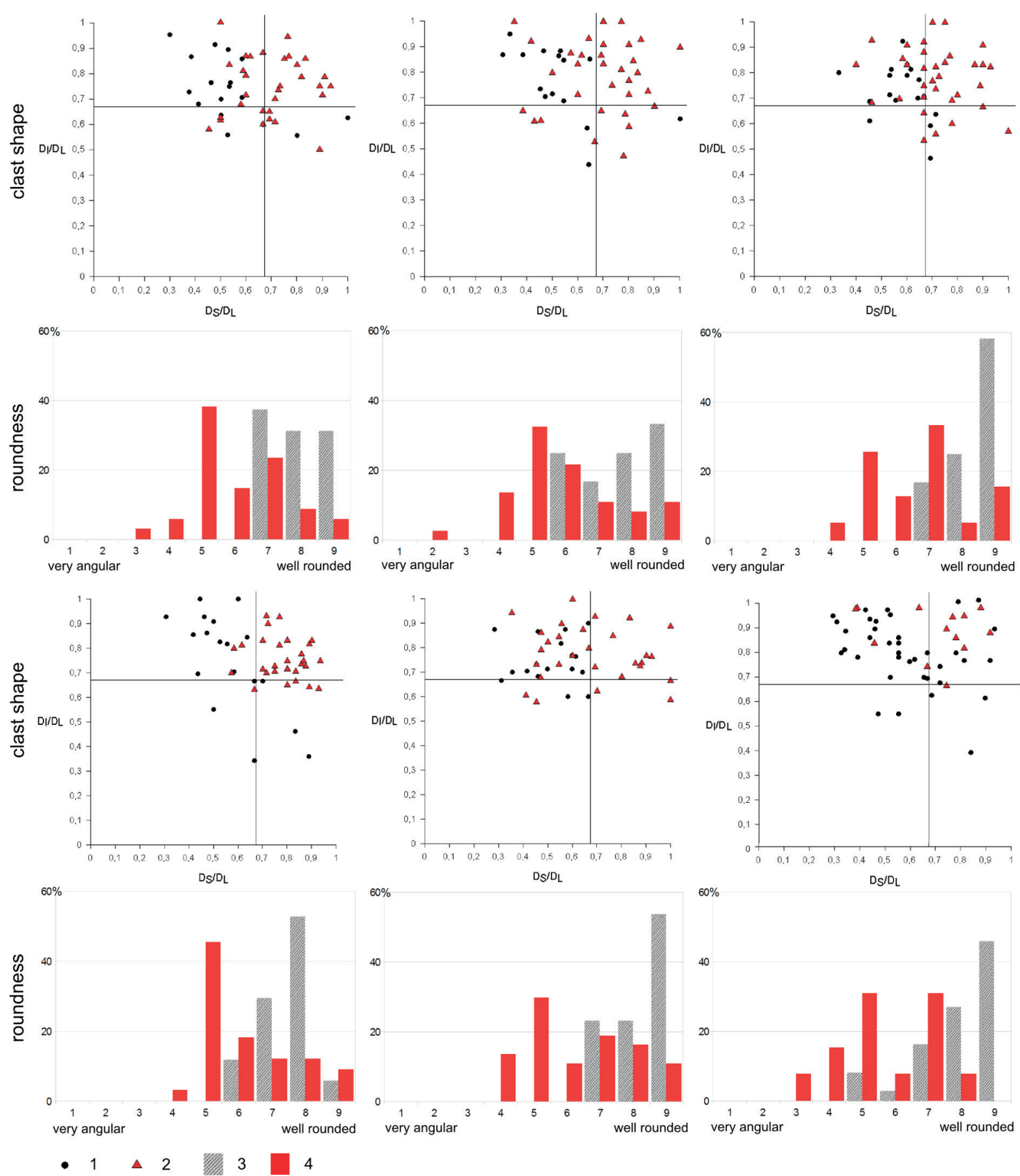

Fig. 7. Grain shape classification using the Zingg diagram (1935) and roundness chart (Krumbein 1941) in the 8-16 mm fraction of gravels of the Rzymsko esker: 1 - local rock, 2 - Fennoscandian erratic, 3 - local rocks, 4 - Fennoscandian erratics

The fennoscandian clasts are most frequently placed in the 5-6 class, although in some samples, another mode occurs in the 7-8 class, which is related to a considerable content of fennoscandian carbonate rocks, which were much more easily abraded during transport than crystalline rocks. Such a high degree of roundness of the local rocks, despite fairly short transport, provides evidence for high energy of the flow present in the tunnel valley. Cretaceous marls of the local bedrock were easily abraded as a result of clasts colliding in streams of high flow competence. Their sharp edges were reduced and their size decreased. Clasts were broken up and finer fractions originated. 

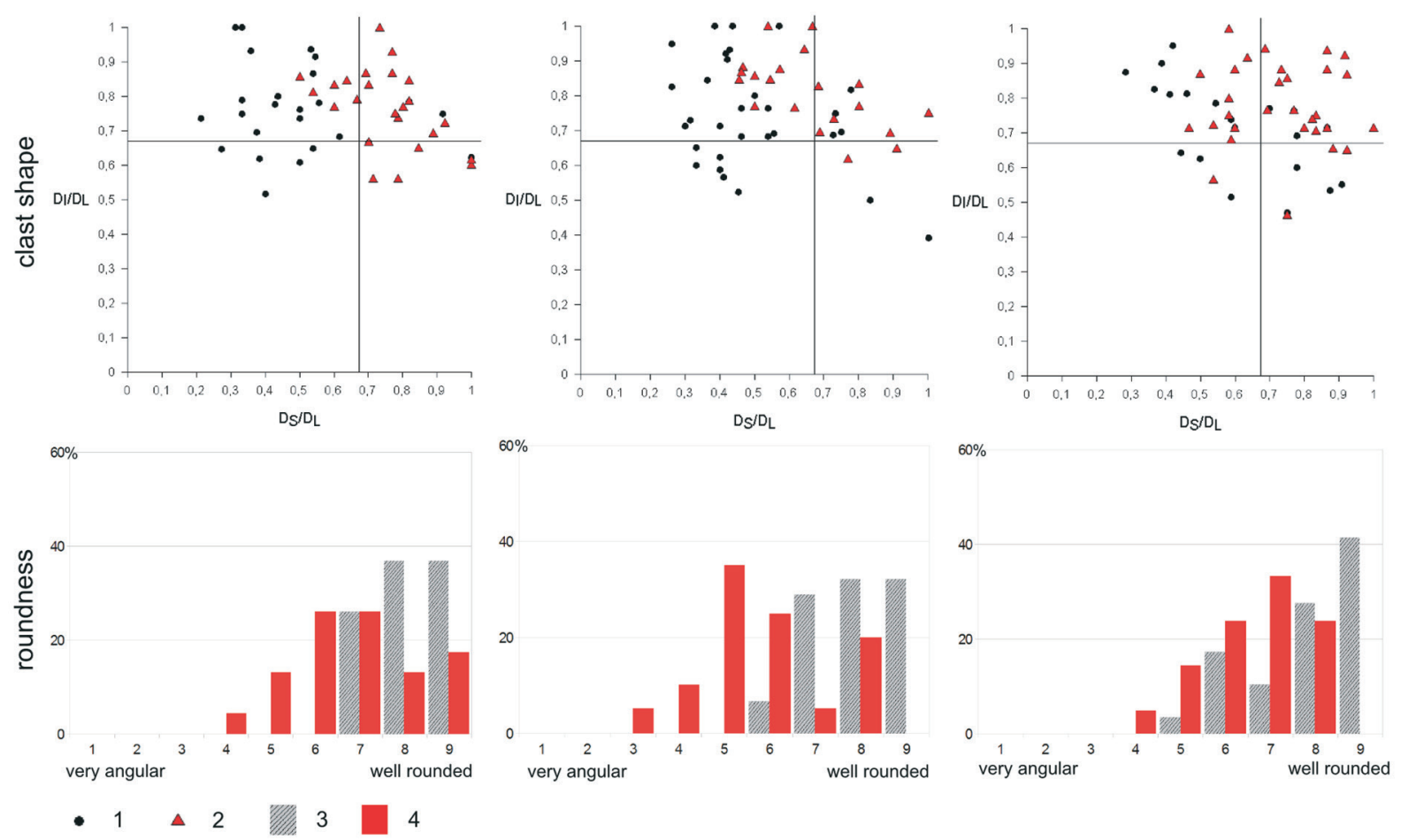

Fig. 8. Grain shape classification using the Zingg diagram (1935) and roundness chart (Krumbein 1941) in the 8-16 mm fraction of gravels of the Rzymsko esker: 1 - local rock, 2 - Fennoscandian erratic, 3 - local rocks, 4 - Fennoscandian erratics

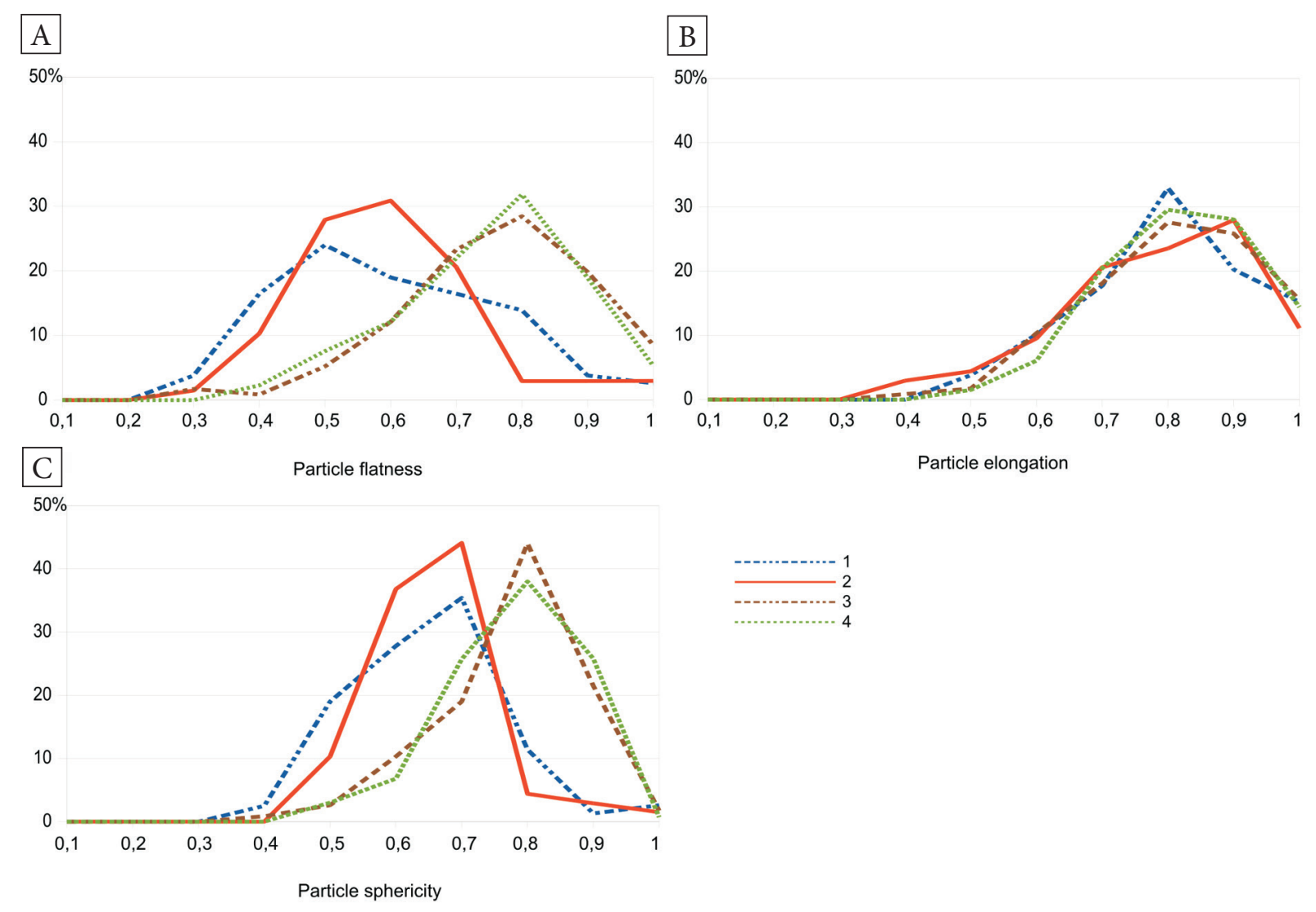

Fig. 9. Distribution of the flatess ratio (A), the elongation ratio (B) and the sphericity (C): 1 - local rocks (16-32 $\mathrm{mm}), 2-$ local rocks (8-16 mm), 3 - Fennoscandian erratics $(16-32 \mathrm{~mm}), 4$ - Fennoscandian erratics $(8-16 \mathrm{~mm})$ 
The fennoscandian material, characterised by a considerably higher hardness than that of the local rocks, was more difficult to process. However, the very high dynamics of the subglacial environment resulted in good roundness of the clasts.

\section{DISCUSSION}

The high variability of sediments and the considerable number of lithofacies which are present in the esker confirm the high dynamics and variability of sedimentation conditions. Accumulation of sediments occurred in a tunnel valley ( $\mathrm{N}$-tunnel), and the far predominant mechanism of sediment transport was hydraulic flow. In the tunnel valley, cyclical floods took place, during which material was transported in the conditions of high-energy flows (Jaksa 2003, Frydrych 2016). This is confirmed by the occurrence of the SGp - Gp - GBp - Gp - SGp lithofacies sequences with normal and inverse grading. There were also episodes of catastrophic flows, recorded in the presence of the BGm and BGp lithofacies. They resulted from increased ablation of the ice or a release of a subglacial, englacial or supraglacial reservoir. In the glacial environment, such sediments have been identified in eskers, in the environment of a tunnel mouth and in outwash plains (particularly those which originated during glacial floods of jökulhlaup type) (Rudoy \& Baker 1993, Zieliński 1993, Mazizels 1991, 1993, 1997, Brennand 1994, Brennand \& Shaw 1996, Russell \& Marren 1999, Fard \& Gruszka 2007).
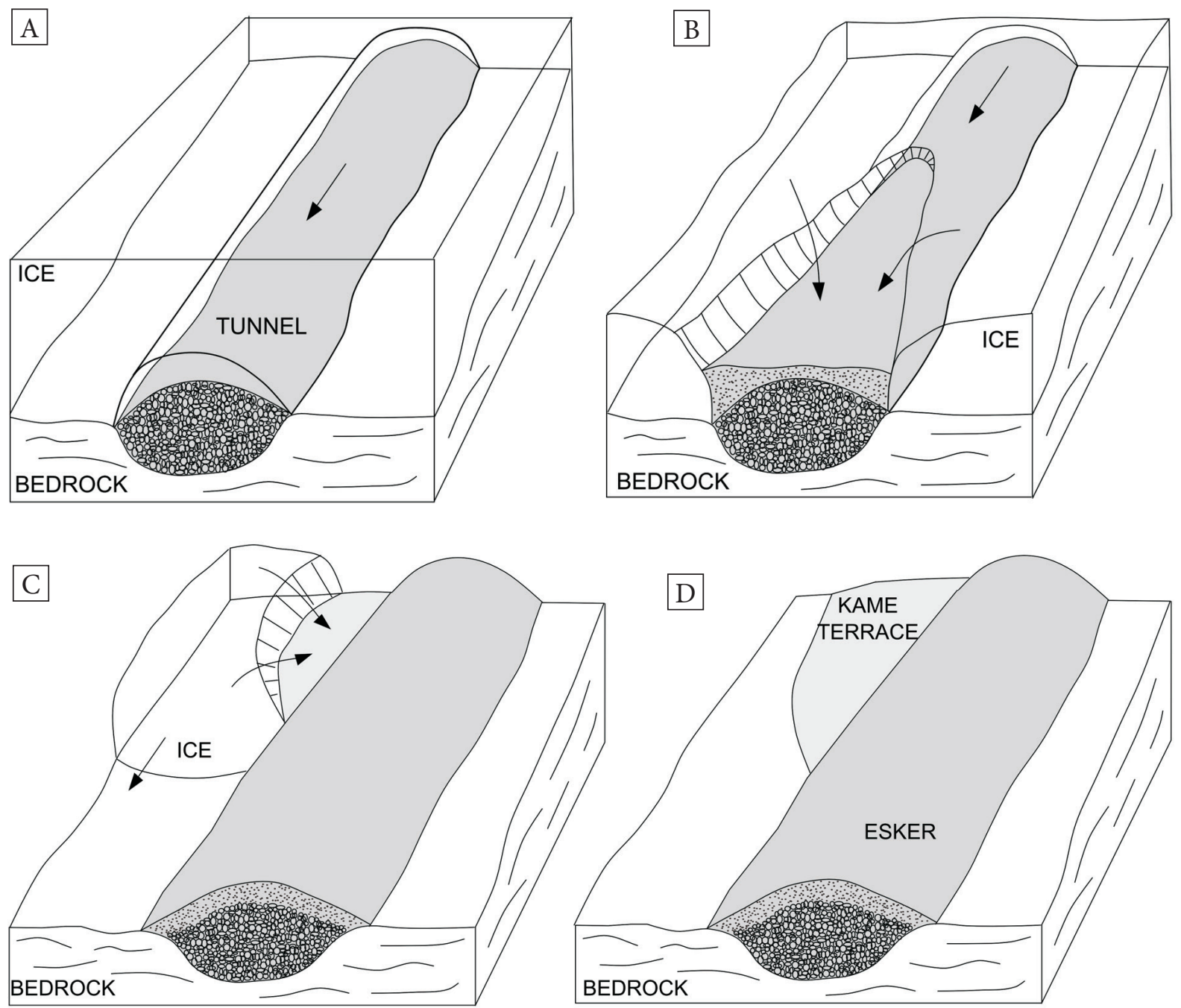

Fig. 10. Phases of the esker development: A) accumulation in a subglacial tunnel; B) accumulation in an open crevasse; C) development of a kame terrace; D) forms after ice sheet retreat. Arrows show directions of meltwater flows 
During catastrophic floods, flow conditions changed from hydraulic flows to hyperconcentrated flow. Average flow velocity was calculated using the formula (Costa 1983) based on MPS and its value exceeded $4 \mathrm{~m} / \mathrm{s}$. This makes it possible to conclude that during floods the value was considerably greater. The value is approximate and it must be kept in mind that the size of clasts largely depends on the availability of material. The massive structure of gravelly sediments and the considerable horizontal extent of lithofacies in the lower part of the esker may indicate sediment accumulation in the conditions of full-pipe flow at the initial stage of its functioning. Unfortunately, no diagnostic features of this type of environment have been determined as yet, which is why it is difficult to present a reliable support for this suggestion (Warren \& Ashley 1994, Fard \& Gruszka 2007, Krupa \& Hojan 2015). Probably, free water surface flow dominated in the tunnel. In the upper part of the succession, the lateral variability of sediments is greater and there are no diamicton sediments present, which may indicate accumulation in an open crevasse. Sediments of the marginal zones of the esker were accumulated in the conditions of lower flow dynamics, and the channels were shallower there. The average flow velocity was usually below $0.5 \mathrm{~m} / \mathrm{s}$. There were incidents of increased flow energy during intensified ice-sheet ablation, recorded in the presence of the SGp lithofacies and erosional strata underlined with gravel surface; there were also episodic debris flows. In its north-western part the esker consists of kame terrace sediments, which provides evidence for continued accumulation in the icefree space between the esker and a block of dead ice (Fig. 10).

\section{CONCLUSIONS}

The considerable diversification of sediments reflects variable dynamics of sediment transport and accumulation within the esker. Its core was dominated by high-energy environment and the flanks - by low-energy environment. The central part of the tunnel was dominated by turbulent flows in the conditions of upper bottom. Average flow velocity was based on MPS and its value exceeded $4 \mathrm{~m} / \mathrm{s}$. During floods the value was considerably greater. In the flanks the average flow velocity was significantly lower - usually below $0.5 \mathrm{~m} / \mathrm{s}$.

The predominant mode of sediment transport in the Rzymsko esker was hydraulic flow, which was periodically transformed into hyperconcentrated flow.

In the tunnel valley, cyclical flooding took place, during which material was transported in the conditions of high-energy flows, and sometimes even catastrophic flows.

The coarse-grained sediments of the Rzymsko esker are characterised by a considerable content of local material, ranging from $30 \%$ to $87 \%$. Such large amount indicates intense bedrock erosion in the glacial drainage system, which must have been incised into Mesozoic sedimentary rocks at some interval along its path.

Locally derived clasts in the gravelly fraction of the esker are very well rounded, and fennoscandian clasts - well rounded. The local material underwent very rapid abrasion in the tunnel valley, despite fairly short transport. In some beds, finer fraction is enriched in grains of local derivation. This is related to rapid and intense rock disintegration.

Local and fennoscandian gravelly clasts are characterised by different preferred shapes. The local grains are much more flat and usually oblate. The fennoscandian clasts usually fall in the equant class. Discoidal marly clasts are more easily transported and may be carried by lower-energy currents, which may also explain their increased content in certain lithofacies.

Among more than twenty documented Wartanian eskers in Central Poland, the Rzymsko esker is characterised by exceptionally high flow energy. In some eskers, gravelly cores were documented, but no sediments reflecting such high flow energy were identified in them.

\section{REFERENCES}

Andrew J. \& Russell P.M.M., 1999. Proglacial fluvial sedimentary sequences in Greenland and Iceland: a case study from active proglacial environments subject to jökulhlaups. Skeiðararsandur, Iceland. Global and Planetary Change, 28, 171-208.

Baker V.R., 1984. Flood sedimentation in bedrock fluvial system. [in:] Koster E.H. \& Steel R.J. (eds.), Sedimentology of Gravels and Conglomerates, Canadian Society of Petroleum Geologists Memoir, 10, Canadian Society of Petroleum Geologists, 87-98. 
Bluck B.J., 1967. Deposition of some Upper Old Red Sandstone conglomerates in the Clyde area: a study in significance of bedding. Scottish Journal of Geology, 3, 139-167.

Brennand T.A., 1994. Macroforms, large bedforms and rhythmic sedimentary sequences in subglacial eskers, south-central Ontario: implications for esker genesis and meltwater regime. Sedimentary Geology, 91, 1-4, 9-55.

Brennand T.A. \& Shaw J., 1996. The Harricana glaciofluvial complex, Abitibi region, Quebec: its genesis and implications for meltwater regime and ice-sheet dynamics. Sedimentary Geology, 102, 221-262.

Brodzikowski K., 1992. Rola i zakres sedymentologicznych badań litofacjalnych we współczesnej geologii i geomorfologii glacjalnej. [in:] Materialy Letniej Szkoły Sedymentologicznej. Problemy sedymentacji glacilimnicznej, Murzynowo k. Płocka, September 1992, Komitet Badań Czwartorzędu PAN, UŁ, 7-53.

Carling P.A., 1996. Morphology, sedimentology and paleohydraulic significance of large gravel dunes, Altai Mts, Siberia. Sedimentology, 43, 647-664.

Carling P.A, 2013. Freshwater megaflood sedimentation: What can we learn about generic processes? Earth-Science Reviews, 125, 87-113.

Carrivick J.L.\& Russell A.J., Tweed F.S., 2004. Geomorphological evidence for jökulhlaups from Kverkfjöll volcano, Iceland. Geomorphology, 63, 1-2, 81-102.

Costa J.E., 1983. Paleohydraulic reconstruction of flashflood peaks from boulder deposits in the Colorado Front Range. Geological Society of America Bulletin, 94 (8), 986-1004.

Czyż J., Forysiak J., Kamiński J. \& Klatkowa H., 2004. Szczegółowa mapa geologiczna Polski 1:50 000. Arkusz Dobra. PIG, Warszawa.

Czyż J., Forysiak J., Kamiński J. \& Klatkowa H., 2008. Objaśnienia do Szczegółowej mapy geologicznej Polski 1:50 000. Arkusz Dobra. PIG, Warszawa.

Delaney C., 2001. Esker Formation and the Nature of Deglaciation: the Ballymahon Esker, Central Ireland. North West Geography, 1, 2, 23-33.

Fard A.M. \& Gruszka B., 2007. Subglacial conditions in a branching Saalian esker in northcentral Poland. Sedimentary Geology, 193, 33-46.

Frydrych M., 2016. Sediments of high-energy meltwater flows: examples from Central Poland, Saalian Glaciation. [in:] Second International Scientific Conference GEOBALCANICA 2016, 10-12 June 2016, Skopje, Republic of Macedonia, Geobalcanica Society, Skopje, 169-176.

Frydrych M. \& Rdzany Z., 2016. Tunnel valleys of old glacial landsystems in Poland. Acta Geobalcanica, 2, 2, 77-84.

Gruszka B., Dobracka E. \& Langer A., 2011. Polygenetic esker in Kluczkowo near Świdwin, NW Poland. [in:] Pisarska-Jamroży M. \& Dobracki R. (red.). Osady glacigeniczne fazy pomorskiej od Uckermark po Równinę Białogardzką, Bogucki Wydawnictwo Naukowe, Poznań, 85-96.

Harvey A.M., 1984. Debris flow and fluwial deposits in Spanish Quaternary alluvial fans: implication for fan morphology. [in:] Koster E.H. \& Steel R.J. (eds.), Sedimentology of gravels and conglomerates, Canadian Society of Petroleum Geologists Memoir, 10, Canadian Society of Petroleum Geologists 123-132.
Jaksa A., 2003. Zmienność sedymentacji w ozie. Stanowisko Rzymsko. [in:] Gruszka B. (red.), Terenowe warsztaty sedymentologiczne, 08-12 września 2003: Kemy i ozy - stary problem w nowym, sedymentologicznym ujęciu, Uniwersytet Śląski, Sosnowiec, 40-45.

Jaksa A. \& Rdzany Z., 2002. Sedymentologiczny zapis dynamiki deglacjacji Wysoczyzny Rawskiej na przykładzie Wału Rylska. Acta Universitatis Nicolai Copernici. Nauki Matematyczno-Przyrodnicze. Geografia, 32, 109, 169-181.

Klatkowa H. \& Załoba M., 1991. Kształtowanie budowy geologicznej i rzeźby południowego pbrzeżenia Basenu Uniejowskiego. [in:] Klatkowa H. (red.), Przejawy glacitektoniki w Polsce Środkowej, Acta Geographica Lodziensia, 72, ŁTN, Łódź, 7-103.

Knudsen O. \& Russell A.J., 2002. Jokulhlaup deposits at the Ásbyrgi Canyon, northern Iceland: sedimentology and implications for flow type. [in:] Snorrason Á., Finnsdóttir H.P. \& Moss M.E. (eds.), The extremes of the extremes: extraordinary floods: proceedings of an international symposium on extraordinary floods held at Reykjavík, Iceland, in July 2000, IAHS Publication 271, International Association of Hydrological Sciences, 107-112.

Kondracki J., 2001. Geografia regionalna Polski. Wydawnictwo Naukowe PWN, Warszawa.

Krumbein W.C., 1941. Measurement and geological significance of shape and roundness of sedimentary particles. Journal of Sedimentary Research, 11, 2, 64-72.

Krupa A. \& Hojan M, 2015. Analiza poglądów na rozwój ozów. Journal of Education, Health and Sport, 5, 12, 717-730.

Maizels J.K., 1983. Proglacial channel systems: change and thresholds for change over long, intermediate and short time-scales. [in:] Collinson J.D. \& Lewin J. (eds.), Modern and Ancient Fluvial Systems, International Association of Sedimentologists Special Publication, 6, John Wiley \& Sons, 251-266.

Maizels J.K., 1991. The origin and evolution of Holocene Sandur deposits in areas of jökulhlaup drainage, Iceland. [in:] Maizels J.K. \& Caseldine C. (eds.), Environmental Change in Iceland: Past and Present, Kluwer Academic Publishing, Dordrecht, 267- 299.

Maizels J.K., 1993. Lithofacies variations within sandur deposits: the role of runoff regime, flow dynamics, and sediment supply characteristics. Sedimentary Geology, 85, 299-325.

Maizels J.K., 1997. Jökulhlaup deposits in proglacial areas. Quaternary Science Reviews, 16, 793-819.

Miall A.D., 1977. A review of the braided-river depositional environment. Earth-Science Reviews, 13, 1-62.

Michalska Z., 1971. Zagadnienia genezy ozów na tle wybranych przykładów z obszaru Polski środkowej. Studia Geologica Polonica, 36, Plejstocen Polski, 7, Wydawnictwa Geologiczne, Warszawa.

Pisarska-Jamroży M., 2006. Transitional deposits between the end moraine and outwash plain in the Pomeranian glaciomarginal zone of NW Poland: a missing component of ice-contact sedimentary models. Boreas, 35,1, $126-141$.

Pisarska-Jamroży M., 2007. Glacifluwialne facje strumieni przeciążonych zawiesiną na przykładzie plejstoceńskich osadów wschodniej Jutlandii i Pomorza Zachodniego. Przeglad Geologiczny, 55, 6, 503-510. 
Pisarska-Jamroży, 2012. Środowisko depozycyjne osadów spływowych jako wskaźnik zmian warunków hydrologicznych strefy marginalnej lądolodu (plejstocen Pomorza Zachodniego). Promotio Geographica Bydgostiensia, 19, 63-79.

Pisarska-Jamroży M. \& Zieliński T., 2014. Pleistocene sandur rhytthms, cycles and megacycles: Interpretation of depositional scenarios and paleoenvironmental conditions. Boreas, 43, 2, 330-348.

Rdzany Z., 2008. Procesy ekstremalne w zapisie osadów i form warciańskich regionu łódzkiego. Landform Analysis, 8, 65-68.

Rdzany Z., 2009. Rekonstrukcja przebiegu zlodowacenia warty $w$ regionie łódzkim. Wydawnictwo UŁ, Łódź.

Rudoy A.N., 2002. Glacier-dammed lakes and geological work of glacial superfloods in the Late Pleistocene, Southern Siberia, Altai Mountains. Quaternary International, 87, 1, 119-140.

Rudoy A.N. \& Baker V.R., 1993. Sedimentary Effects of cataclysmic late Pleistocene glacial Flooding, Altai Mountains, Siberia. Sedimentary Geology, 85, 1-4, 53-62.

Russel A.J \& Marren P.M., 1999, Proglacial fluvial sedimentary sequences in Greenland and Iceland: a case study from active proglacial environments subject to jökulhlaups. [in.] Jones A.P, Hart J.K. \& Trucker M. (eds.), The Description and Analysis of Quaternary Statigraphic Field Sections, Quaternary Research Association, 171-208.

Saunderson H.C., 1981. Tunnel transformation of antidunes. Physical Geography, 2, 125-145.

Salamon T., 2009. Subglacjalne pochodzenie przełomowych dolin zachodniej części progu środkowotriasowego i ciągu pagórów okolic Gogolina. Przegląd Geologiczny, 57, $3,243-251$
Sneed E.D. \& Folk R.L., 1958. Pebbles in the lower Colorado River, Texas: A study in particle morphogenesis. Journal of Geology, 66, 114-150.

Szmańda J.B., 2010. Litodynamiczna interpretacja środowiska fluwialnego na podstawie wskaźników uziarnienia: przegląd wybranych metod. Landform Analysis, 12, 109-125.

Warren W.P. \& Ashley G.M., 1994. Origins oft the ice - contact stratified ridges (esker) of Ireland. Journal of Sedimentary Research A: Sedimentary Petrology and Processes, A64, 3.

Wentworth C.R., 1922. A scale of grade and class terms for clastic sediments. Journal of Geology, 30, 377-392.

Wyżga B., 1993. Present-Day Changes in the Hydrologic Regime of the Raba River (Carpathians, Poland) as Inferred from Facies Pattern and Channel Geometry. [in:] M. Marzo \& C. Puigdefabregas, Alluvial Sedimentation, Special Publication of the IAS, 17, John Wiley \& Sons, 305-316

Zieliński T., 1992. Proglacial valley facies of the Silesian Upland - genetic factors and their sedimentological effects. Geologia Sudetica, 26, 1-170, 83-118.

Zieliński T., 1993. Sandry Polski pótnocno-wschodniej: osady i warunki sedymentacji. Uniwersytet Śląski, Katowice.

Zieliński T., 2015. Sedymentologia. Osady rzek i jezior. Wydawnictwo Naukowe UAM, Poznań.

Zieliński T. \& Pisarska-Jamroży M., 2012. Jakie cechy litologiczne osadów warto kodować, a jakie nie? Przegląd Geologiczny, 60, 7, 387-397.

Zielinski T. \& van Loon A., 2003. Pleistocene sandur deposits represent braidplains, not alluvial fans. Boreas, 32, 4, 590-611.

Zingg T., 1935. Beiträg zur Schotteranalyse. Schweizerische Mineralogische und Petrographische Mitteilungen, 15, 39-140. 